\title{
AVALIAÇÃO DE CARACTERÍSTICAS AGRONÔMICAS DE CULTIVARES DE ALFACE SOB DIFERENTES DOSES DE TERMOFOSFATO MAGNESIANO
}

\author{
Adrielly Almeida Guimarães Severino' \\ Letícia Martins de Sousa ${ }^{2}$ \\ José Hortêncio Mota ${ }^{3}$
}

\begin{abstract}
Resumo: Este estudo teve por objetivo avaliar a aplicação de doses de $\mathrm{P}_{2} \mathrm{O}_{5}$ na forma de termofosfato magnesiano $\left(\right.$ Yoorin $\left.^{\circledR}\right)$ no desenvolvimento de alface do tipo americana cv. Lucy Brown em Jataí-GO. Foram avaliadas cinco doses (0; 75; 150; 225 e $300 \mathrm{~kg} \mathrm{ha}^{-1}$ ) de termofosfato magnesiano em um delineamento de blocos casualizados com 4 repetições. As características avaliadas foram o peso total, peso comercial, peso de caule, número de folhas, diâmetro e circunferência de caule e teor de massa seca. Verificou-se que ocorreu efeito significativo para as doses de $\mathrm{P}_{2} \mathrm{O}_{5}$ apenas para as variáveis produção total e comercial, peso de caule e número de folhas. As máximas produções total e comercial obtidas foram de 387,06 e 250,28 g planta $^{-1}$, para doses de 205, 8 e 214,75 $\mathrm{kg} \mathrm{ha}^{-1}$ de $\mathrm{P}_{2} \mathrm{O}_{5}$, respectivamente.
\end{abstract}

Palavras-chave: Lactuca sativa L., Yoorin®, adubação fosfatada.

\footnotetext{
${ }^{1}$ Universidade Federal de Goiás - Regional Jataí, Cx Postal 3, 75801-615, Jataí - Go, adriellyagseverino@gmail.com.

${ }^{2}$ Universidade Federal de Goiás - Regional Jataí, Cx Postal 3, 75801-615, Jataí - GO, leticia.martins.agro@gmail.com

3Universidade Federal de Goiás - Regional Jataí, Cx Postal 3, 75801-615, Jataí - GO, hortenciomota@ufg.br.
} 